\title{
The Legal Nature of the Electronic Contract (comparative study)
}

\author{
Dr Yassin Ahmad alqudah \\ College of Law,Middle East University
}

Dr. Raed Mohammad Flieh Alnimer

College of Law, Royal University for Women

\begin{abstract}
There is no doubt that the huge development in the revolution of communications and modern technologies in addition to modern technological development in general led to the emergence of electronic commerce through which the electronic contract. It is necessary to shed light on this modern type of transaction to clarify the nature of the laws and provisions that govern it, so as to provide legal protection for the clients in this field. For this reason, I have considered dealing with this area, which will require legal systems to be subject to the provisions and laws necessary to settle disputes that may arise, and to high light on the nature of the electronic contract by holding it and proving it only. The Internet has been one of the most important innovations of the human mind in the field of informatics since the end of the last century. It removed geographical boundaries between countries and helped to turn the world into a small village and developed e-commerce. The Internet is one of the most important means through which Conclusion of electronic contracts. The electronic contract is validated by verifying the validity of the pillars: the object, the cause, the agreement and the eligibility, which are organized in the same framework as the general rules regulating the traditional contract. With some specificity of these pillars, the scope of the general rules is not broadened; to accommodate the eligibility of the contractors, it is difficult to ascertain the identity of the contracting parties and their eligibility, electronic signature and certification to try and fill gaps in this range.
\end{abstract}

Keywords:

revolution of communications, electronic commerce, electronic contract, Electronic Offer, electronic acceptance, object, consideration.

\section{Introduction}

The amazing technological development in the field of information and communication technology which we are witnessing today has led to the emergence of a new type of transaction that was not known before. The various means of communication and information technology, in particular the Internet, were used to conclude contracts. Transactions and contracts concluded on a daily basis through the Internet. These online contracts are part of e-commerce business today.

E-commerce has grown exponentially and rapidly, reflecting the volume of trade in which it has exceeded billions of dollars in a relatively short period of time. Electronic commerce has become a prominent feature of the trade of the age. The Internet has become a commercial center for all the inhabitants of the earth and display the products for sale through the so-called virtual stores which occupied the web pages. This type of trade has saved time and effort reduced costs and expenses as the virtual store on the network does a job to avoid resort to open a shop which is expensive. On the other hand, the consumer can demand the commodity he wants without leaning his place, at any time, around the clock, and at a much lower price than those sold in traditional stores. In order to protect this consumer, the majority of e-commerce laws provide for the right to return the item within a specific period of time 
from the date of receipt or from the date of conclusion of the contract.

As a result of the steady increase in e-commerce transactions that have led to a significant increase in electronic contracts. This trade has become a practical reality at the national and international levels, leading to UNCITRAL's adoption of the UNCITRAL Model Law on Electronic Commerce in 1996, as a guiding law that could be used when States were enacting their national legislation on electronic commerce. As a result of the increase in e-contracting at the national level this has created the need for enacting national e-transactions legislation as a result of the many legal challenges facing the e-contract which prompted the majority of Arab countries to issue e-transaction laws to address these challenges. The contractual nature of the contracting parties, the legal nature of the contract, the liability incurred in the negotiations stage in the event of its termination, and the legal problems related to the expression of the offer, acceptance, the letter and whether a contract between present or absent. The importance of the Council of the contract in terms of determining the time and the place of the contract and the legal theories that dealt with this issue and try to know the possibility of applying the general theory of the contract on electronic contracting through various means of communication, especially those that take place over the Internet are more common and used.

\section{2.Electronic contract}

Electronic contracts are growingrapidly and accounting for a huge share of international and domestic trade. A specially in developed countries due to the ease and speed of contracts. This has become even more so since the global commercial establishments are refusing to deal with any new customer who does not use the method of electronic contracting. This requires dealing with the electronic contract and distinguishing it from other contracts from different legal aspects.

\section{1. definition of $\mathbf{E}$ - contract}

The source of the obligation is the "legal reason that created the obligation", i.e. the reason for the obligation of a person to pay money to another person. For example, the tenant pays the owner of the property and the source of the obligation is the contract. The traditional arrangement of sources of compliance in Latin laws divides these sources to five, namely contract, quasi-contract, crime, quasi-crime and law ${ }^{1}$.

In this context, attention will be given to the contract as one of these sources. A contract is an agreement where a proposal is made and subsequently accepted with the intent of creating a certain legal effect.

An electronic contract is an agreement in which the offer is accepted by an international network that is open to remote communication, in a way that may be audible through the interaction between the offeror and the offeree. This shows that the electronic contract belongs to the group of contracts that legal persons have defined as contracts concluded remotely. Article (2) of the Jordanian Electronic Transactions Law No. (85) of 2001 defines the electronic contract as "the agreement which is concluded by electronic methods, in whole or in part"2.

The contract is generally in the form of the convergence of two or more wills to create a certain legal effect and the contract is the law of contract which is known in the law of the AngloAmerican States. It should be noted that the contract in terms of composition is either consensual in kind and in terms of impact either be unilateral contract - or unilateral contract- or a contract of netting or a donation contract which in nature is either an immediate contract or an ongoing contract, or a limited contract or a potential contract. The electronic contract actually does not come out in its structure, types and

\footnotetext{
1- AQ Alfar,Sources of obligation, sources of personal right in civil law, First Edition, Jordan, International Scientific House, and Dar Al Thaqafa Library for Publishing and Distribution, 2001, p29.

2. Jordanian Electronic Transactions Law No. (85) of 2001.
} 
content from this context and is subject to its organization of the provisions contained in the general theory of the contract. This is an unnamed contract where the legislator did not put in the laws in question a special organization. An electronic contract is an agreement in which the offer is accepted by an international network that is open to remote communication, in a way that may be audible through the interaction between the offeror and the offeree. Contracts that legal persons have defined as contracts concluded remotely ${ }^{3}$.

At the international level, the UNCITRAL Model Law on commerce did not provide define for Econtract, however in the first paragraph of Article 11 , under the title of contract formation and validity, it is permissible to use data messages to express the offer and accept the offer in the context of contract formation, unless the parties to the contract agree otherwise. (UNCITRAL Model Law on Electronic Commerce.).

It is noted from the aforementioned definitions that the electronic contract is not limited to the contract concluded through the Internet, but includes all contracts made via other electronic methods of communication, such as fax, telex and facsimile.

The electronic contract is not different from the normal contract in the pillars of concluded, the conditions of its validity and the impact of it in terms of responsibility but differs in the way it is concluded as it acquires the electronic form of the way it is held and meet the offer of the person who has offered with the acceptance by the communication between the contractors via audio visual through an international network Open to remote communication, and when the electronic contract is no more than a normal contract is no different except in the way it is held through modern means of communication such as the Internet. It is necessary to submit to the regulation

\footnotetext{
3 - IK Mamdouh,Conclusion of the Electronic Contract comparative study, First Edition, Alexandria, published dar alfjeraljamee, 2006, P5.
}

established by the legislator for the ordinary contract. Where the Decree Law No. (19) for the year 2001 issued the Civil Code and stipulated in the article 29 that the contract "A contract is an agreement where a proposal is made and subsequently accepted with the intent of creating a certain legal effect". As well as a text in the article 30 stipulates" A contract is created, subject to any special formalities that may be required by law for its conclusion, from the moment that two persons have exchanged two concordant intentions without prejudice to the requirements of the law in special cases in terms of certain requirements for rendering the validity of such contract".

Therefore, the contract is the consensus of the two willsor more with the intent of creating a certain legal effect, Consent is the strength of the contract. Consent goes to the creation of the obligation and each obligation has to have a cause andobject. This is the traditional contract according to the general theory of obligation.

If the electronic contract is regulated by the general rules and provisions governed by the general theory of the contract in general but differs in the way it is concluded, it is a contract between absentees using modern electronic media.

As stated in Article 10 oflegislative Decree No 28 of 2002 with respect to electronic transaction regard to acceptance and offer of the electronic contract, that it is permissible and according to the agreement of the parties, as stated in the above article that: "In the context of the formation of the contracts, unless otherwise agreed by the parties, an offer and the acceptance of an offer or any other matter that is material to the formation to operation of a contract including any subsequent amendment or cancellation or revocation of the offer or acceptance of the offer, may be expressed in whole or in part by means of electronic records".

\section{2 distinguished electronic contract from other contracts}


The manner in which the electronic contract is concluded is the most important aspect of its privacy, as it appears to belong to the range of contracts concluded remotely knowing that it does not constitute a new type of contract added to traditional contracts traded legally, nor does it completely depart from the legal rules governing the provisions of the contract in general which are contained in civil laws. Yet electronic contracting is distinct from the conventional image of the contract and thus can be summarized the most important characteristics that characterize it as follows:

First: - Conclusion of the electronic contract without the physical presence of the parties.

It is a remote contract consisting of a set of technical procedures for audio and video to send and receive information since the contract is held remotely through modern communication technologies and without the personal presence of the contractors as lead to the realization of many economic advantages for businesses and customers both.

As for the tourism projects, the use of e-contracts in their business transactions reduced the internal expenses of these projects and minimize the number of workers, and the possibility of direct contactwith customers in their homes, and for customers, it saves time and effort. This type of goods and services enriches the need for the store where you are located Product or service, or wait in line to get a specific product.

Second: Use of electronic media in its conclusion

This is considered one of the most important aspects of privacy in the electronic contract. The electronic contract, as mentioned earlier, is not different in terms of subject matter and parties than other traditional contracts but differs in terms of the way it is concluded and being concluded using electronic media. The importance of electronic media is that it has made the electronic contract a cross-border contract. It has dismantled the world band and abolished the political boundaries between countries, so that information flows freely across the borders of different countries. While the traditional contracts with a physical presence of the parties in a single council in which the offer and acceptance is at the same place and time ${ }^{4}$.

Third: The electronic contract is verified and fulfilled in a special way

The normal writing is the basis of proof which means that the paper pillar in the official and customary texts is the embodiment of the material existence of the ordinary contract. The writing is not a complete evidence of proof unless it is signed by the ordinary signature, in one of the forms as a handwritten signature or fingerprint or stamp.This is what the existing legal texts have defined to substantiate current transactions. While online services have enabled a new type of esignature to be signed and signed in electronic form (the electronic signature).This means that online contracts made specifically through the Internet are always unsupported on paper support, and this is Unlike traditional contracts.

In terms of fulfill, electronic money has replaced ordinary money and electronic money can take forms including, but not limited to, programmed electronic cash, magnetic plastic cards and electronic checks, etc.

In addition to the electronic methods and methods mentioned above, the e-contract can be performed in traditional ways. Thus, the methods of performance of the contract in e-contracts differ from the traditional contracts in which the allowance is paid in the conventional method only 5 .

\footnotetext{
4 - AS Hamid, Contracting through modern communication techniques (comparative study), First Edition. Cairo: Dar Al-Nahda Al Arabia,2006, P73.

5 - A A Rahim,Consensus in Electronic Contracts via the Internet a Comparative Analytical Study in the Light of the Iraqi Civil Code and the Laws of Commerce and Electronic Transactions in (USA, Canada, Tunisia, Jordan, Kingdom of Bahrain, Emirate of Dubai) and the UNCITRAL Model Law
} 


\section{3- pillars of electronic contract}

The contract is governed by the general rules, governed by the general contract theory. It is concluded by agreement and consent between the parties, but it is characterized as a remote contract using electronic means.

\subsection{Availability of Consent}

Consent is one of the cornerstones of the contract, which is held by mutual consent with a view to create a legal effect. Consent is present if the wills of the contractors are met and the conditions of the validity ofthe conciliation are satisfied the contract is concluded ${ }^{6}$.

In order for there to be consensual, there must be a will on both sides of the contract. The will prevail, if it is issued by those who have the ability to know the consequences of the will. The will of the psychological work does not affect what remained inherent with the same owner.The law should be willing to take an external appearance with indicating, for the contract to be concluded ingeneral. Theoffer must be issued by anyone of the contractors followed by acceptance or the other party,and that both the offer and the acceptance are conformable ${ }^{7}$.

\subsubsection{Concept of Electronic Offer}

The offer is an expression of the will of the contractor, which indicates conclusively that he accepts the contract under certain conditions. This is what article 37 of the Bahraini Civil Code defines as:"A proposal is an offer made by a person to another person of his intention to conclude a certain contract merely by acceptance of the person to whom it is offered. It shall include at least the nature of the contract required to be concluded and its fundamental conditions" 8 .

on Electronic Commerce. First Edition. Amman: Wail Publishing library, 2006, P74.

6 - AA Al-Manan,The legal framework of the electronic contract, first edition, 2008, P 68.

7 - O A Mujahid, Online contracting, Legal Library, Egypt, 2005, P80.

8 - Bahrain civil law
Therefore, the expression of will must be considered offer and must include all the essential elements of the contract ${ }^{9}$.

The Vienna Convention of 1980 on the International sale of Goods in Article 14.1 established a criterion for determining the claim, stating that "(1) A proposal for concluding a contract addressed to one or morespecific persons constitute an offer if it is sufficiently definite and indicates the intention of the offeror to be bound in case of acceptance. A proposal is sufficiently definite if it indicates the goods and expressly or implicitly fixes or makes provision for determining the quantity and the price. (2) A proposal other than one addressed to one or more specific -persons is to be considered merely as an invitation to make offers, unless the contrary is clearly indicated by the person making the proposal" 10 .

As for the definition of the offer on the electronic contract, it was defined by the European Directive of 20/5/1997 (07 of 20 May 1997 of the European Parliament - article 2 of Directive No. 97 on remote contracting and consumer protection in this areastates that it is intended to contract remotely: "Any contract relating to goods or services entered into between a supplier and a consumer within the scope of a sale system Or the provision of remote services by the supplier who uses one or more telecommunications technologies to contract or execute the contract. "The telecommuting technique in the same text defines" all means without physical and immediate presence of the supplier and the consumer could be used to conclude the contract between the parties ", This guidance has defined contracts remotely which include the concept of electronic contracts.

It is clear from this definition that did not define or determine the means of electronic

\footnotetext{
9 - S Anwar, The General Theory of obligations. part One. Second Edition. Egypt: Dar Al Ma'arif.1958, P 72. 10 - United Nations Convention on Contracts for the International Sale of Goods, 1980.
} 
communication remotely, nor didn't highlight the most important characteristics of the electronic offer, which is the electronic character of this offer. It is clear that the elements of the offer should be included in the offer so that the person can accept it.

An electronic word, if added to the offer, does not affect its meaning in accordance with the general theory of obligations. The question is merely a description of no more because of the different means of expression of will. The expression in the electronic contract is embodied in modern means of communication via the computer. This computer may be expressed electronically via email or through a website or through the conversation.

\subsubsection{1:offer via e-mail}

The e-mail offer is intended to be the offer to specific persons in the event that the trader wishes to allocate the offer to persons who he believes may care about his product without other members of the public. Noting that the offer is either directed for one person only or for a number of persons and that the offer directed at one person is a non-binding offer unless the offer during a certain period is committed by the offeror to remain valid throughout that period. In the case of non-binding offer, it may be rejected by e-mail if the offeree closes or scroll to the computer Signed other than the offeror site ${ }^{11}$.

If an offer directed to a number of persons, it is a mere invitation to negotiate or contract. This is not an offer based on the fact that the publication, declaration, press statement currently being processed or requests addressed to the public is not considered in doubt offer but be an invitation to contract.

\subsubsection{2 offer via web pages}

This type of offer is not very different from the offer issued by newspapers or television

\footnotetext{
11 - KH Abdel Rahman, Expression of Will in the Electronic Contract, Dar Al-Nahda Al Arabiya, Cairo,2005, P44.
}

because it is a continuously offeredall the time and the offer is mostly directed to the public and not to a specific individual. The offer issued through the web pages is not limited in time and determined by the entry of the quantity or a reasonable period as in the traditional offer. It is only in such a case is the full offer if he completes its general conditions $^{12}$.

\subsubsection{3. offer via conversation or viewing}

Here, the online trader can see the caller on the computer screen and talk to him through a computer camera on both sides. In this case, offer Issued by one of the parties and will is met with an acceptance by the other party. The contract is deemed to have been concluded if acceptance conforms with the offer, and we accept the contract between presentparties.

In fact, the issuance of the offer should be preceded by negotiation stages before the conclusion of the contract, Since the electronic offer is remote, the final contract remotely often directed from a professional trader to the consumer community is subjected to the rules of consumer protection. This imposes on the merchant or professional contractor many obligations towards the consumer, in particular the identification of the seller and his address, sold item, service provided, descriptions, the price, method of payment or payment and the consumer's choice to refer to the contract within the period specified by law. Also to re-notify the consumer of the previous offer within a period not exceeding the re-delivery, the warranty period and the after-sale service ${ }^{13}$.

The e-offer via internet characterized by an intermediary offering the offer and publishing it on behalf of the offeror. For this reason, the

12 - KM Ibrahim, conclusion of the electronic contract, the Arab Thought House, Alexandria, 2006.P78.

13 - OA Badr, Consumer Protection in Electronic Contracting, Comparative Study, New University Publishing House, Alexandria, 2005, P143. 
offer is not effective for the sake of its issuance, but rather its presentation on the site. This offer validates the legal existence of the offer and is valid to arrange its effects.

The e-offer disappears as soon as it is withdrawn from its site. In this case it has no legal effect and does not have a valid presence, since it will not be available to the public.

It is noted that goods and services are often advertised through the Internet and can be defined as "any form of communication in the context of a commercial, industrial or artistic activity intended to promote the supply of objects or services." The Opinions differ on the boundary between the offer and the advertising. The opinion of this view that the declaration is not considered offer, but an invitation to the contract because of not to designate the person intended offer as well as the kind of moral pressure on the consumer and inciting him to buy unnecessary goods ${ }^{14}$.

The other opinion considers that the advertising which directed to the public via the Internet as an offer. We tend to the second opinion as long as it contains the basic elements of the contract to be concluded, as if it specifically contains a specific product or service, denying the price. If the advertisement does not include it, it is no longer just a call to contract $^{15}$.

\section{2. expiration of the e- offer}

In many cases the offer has expired but there is a difference here between binding offer and non-binding. In the binding offer,the offer is lost either by the expiry of the period without the acceptance or refusal of the offeree even

14 - OA Badr, Consumer Protection in Electronic Contracting, Comparative Study, New University Publishing House, Alexandria, 2005, P144.

15 -S H Al-Gammal, Contracting Through Modern Communication Technologies, First Edition, Dar Al-Nahda Al-Arabiya, Cairo,2000, P187. before the expiry of the period. An acceptance that goes beyond the offer, or that is accompanied by a restriction or a modification is deemed to be a rejection comprising a new offer. While the Non-binding offer is only in contract between two presenters in the same time of contract, the contract falls in two cases:1- Modification of the offer by the offeror before the dissolution of the council of the contract .2- The dissolution of the Council of the contract whether or not the offeror renunciation in his offer or not ${ }^{16}$.

\section{Acceptance of the electronic contract}

An acceptance is the second will in the contract from which the offeree is charged. The firm intention of the contract must include any unconditionally issued contract because the electronic contract is mostly a contract of consumption. The electronic acceptance is not final and therefore the contract is not obliging for the consumer.In another word an acceptance is an unqualified expression of assent to the terms proposed by the offeror.

The electronic acceptance corresponds to its content with the previous meaning, all the matter is that it is through an electronic medium and is usually issued most likely to the consumer and is remote. If the normal acceptance may be express or implied, the electronic acceptance is not explicit, whether by using an explicit and direct term that indicates the intended meaning. It is either through telephone communication, Internet or written conversation MIRC, e-mail at a time that the consumer will accept it in the form of a mail message through an e-mail program.The content of the acceptance is written in the subject line, and then simply press the submit button to direct the message to the Professional's email list ${ }^{17}$.

\footnotetext{
16 - MA Al Roumi,Online E-Contract, First Edition, University Press House, Alexandria,2004, P89. 17 - IA Abu-Lil,Legal Aspects of Electronic Transactions, Scientific Publishing Council, Kuwait,2003, P204.
} 
While the silence taking a negative attitude does not indicate a particular will that is considered acceptable if it is adopted by certain circumstances indicating that the offeror was not waiting for an acceptance to his offer. This is stated in Article 42 of the Bahraini Civil Code" a) No statement is ascribed to a silent. However, a silence in connection with a need is a statement. (b) Failure to reply is equivalent to acceptance in particular when the offer relates to dealings already existing between the parties, or when the offer is solely in the interest of the offeree". Therefore, we asked whether it is correct to remain silent in order to express the electronic acceptance?

There are several opinions on this subject that the silence of one of the contractors in the previous deal between them online can be deduced from the same as the acceptance of the ordinary. Another aspect of the jurisprudence is that silence is not valid to express electronic acceptance. Therefore, the recipient of an electronic message via the Internet contains an offer stipulation that if he did not respond to this offer within a certain period considered acceptable ${ }^{18}$.

In our opinion, it is very difficult to consider silence as an expression of acceptance of online contracting in accordance with the provisions of Article 42 of the Civil Code. With a virtual shop across the network, by sending the merchant, for example an e-mail and not respond to them during a certain period as acceptance of the offer in the circumstances of the previous deal is not enough to consider it to be silent in the contract online.

The French Model Contract on E-Commerce indicated that the buyer's consent should include specific elements such as the thing or service contracted, the price, the manner of fulfillment, the manner of delivery and the manner in which the post-sale service is performed, it is clear that

\footnotetext{
18 - M M Mabrouk, The Authenticity of the Electronic Signature in Proof, Dar Al-Nahda Al-Arabiya, Cairo, 2011, P79.
}

the reference to these key elements of the contract, which does not exist without agreement.

For the contract to initiate and be in force, the party who received the offer must illustrate consent. Acceptance can vary in form; it can be explicitly, implicitly, verbally, in writing or alternatively, by sign. For example, consenting to the tender document offered. The combination of offer action and acceptance is of great importance in determining the time and place of the contract.

Contracts are concluded online by sending the contract form to the purchaser's page to enable him to review its terms. The contract form contains boxes containing the terms of acceptance of the contract (yes) or rejection (no) and is accepted as soon as the consignee clicks on the acceptance key on the computer or by pressing the cursor on the selected cell to accept the contract you may be accepted by telephone, internet, chat rooms, e-mail ${ }^{19}$.

The electronic acceptance is also defined as theofferee expression by the data message in whole or in part for its offer satisfaction as issued by the offeror. More over the Bahraini legislator stipulates in article 3 of legislative Decree No.28 of 2002 with respect toelectronic transaction that:" 1. Nothing in this Law shall require a person to send, receive or display any electronic record or signature except upon explicitly obtaining their consent. Except for the public bodies, the consent may be implicitly given through a positive behavior.2. Nothing in this Law shall prohibit a person engaging in an electronic transaction from establishing his own reasonable requirements about the manner in which to accept an electronic signature or electronic records".

\section{1. $E$ - contracting council}

The privacy of an electronic contract is that it is made through an electronic network such as the Internet and belongs to the range of remote

\footnotetext{
19 - AA Ajlouni, Online Contracting, Master Thesis, University of Jordan,2002, P56.
} 
contracts where the contract is between people who are spatially separated and thus can be entered into the contract in the form of contracts between absentees such as contracting by telephone, but this does not necessarily mean that the e-contract follows this range of contracts. Some legal systems have considered that the contract via telephone is a form of contract between those present in terms of time because the parties are in direct contact and Others considered it a compromise between the two contracting situations.

The contract council has a great importance in the formation of the contract which is considered the most important stage after the negotiations stage and then the period of agreement or project. The importance of the contract council has emerged after the spread of modern means of communication, its development and reached a stage in which the two contractors are joined by the legal Counsel,and closer to the real contract that is among those present ${ }^{20}$.

\subsubsection{The concept of contract council}

Al-Senhoury as a legal jurisprudence believes that from his point ofview, that the theory of the Contract council has not been dealt with specifically in French jurisprudence. In the other hand Islamic jurisprudence has formulated a theory of great perfection, so that the other contractor should not be accepted immediately, but that he may have to take some time. On the other hand, he is not permitted to rely on leniency to the extent of harming the offeror by keeping him suspended for a long period without responding to his favor. Therefore, there is a need to mediate between the two issues, hence the theory of the contract council Created.

The contract council is the space unit in which the contractor remains or is the unit of time, i.e., The length of time in which the contractors remain

\footnotetext{
20 - C Monaghan, N Monaghan, Beginning contract law, Routlege taylor\&francis group, London and New York,2014, P108.
}

engaged even if the place changes. The contract is intended to give contractors sufficient time in the period of the contract to be in charge of the contract. They have been given the thought and deliberation of the council of the contract and until its dissolution.Thus the idea of thecontract council is that both the offer and the acceptance are not binding as long as they are not met, proving to the offeror the option of returning from his favor and proving to the offeree is the option of acceptance or rejection as long as the Council is not dissolved.

This was supported by the text of article 40of Bahraini civil code which stipulates:" If at the time a contract is being framed and an offer is made without a time limit being fixed for acceptance, the offeror is released from his offer if it is not accepted forthwith. This also applies, if the offer is made by one person to another person by telephone or by any other similar means as long as no time limit is fixed for acceptance.A contract is concluded, however, even if acceptance is not immediate, when during the interval between offer and acceptance, there is nothing to indicate that the offeror has withdrawn his offer and the declaration of acceptance is made before the end of the meeting at which the contract was being framed".

\section{2. methods of e- contracting}

The contract councilvaries into two types: Real and Legal. For the Real type, the council collects contractors in one place and hears each other so that it begins by offering the offer and ends either by accepting or rejecting the offer. As for the legal contract, it is the council where one of the contractors is not present.The duration of the econtract council is determined according to the method of contracting.

\subsubsection{Contracting via e-mail}

A - If there is a time interval between the offer and acceptance, there is no doubt that the contract is between absent time and place. 
B - The state of an offer and acceptance at the same time, and is via the phone and that the offer and acceptance are at the same time, the contract must be applied between those present at the time for a while.

\section{However,article 10 of UNIDROIT PRINCIPLES OF INTERNATIONAL COMMERCIAL} CONTRACTS 2016, mentioned in regard of notice via email to the effect time of notice, which stipulates that:" (1) Where notice is required it may be given by any means appropriate to the circumstances. (2) A notice is effective when it reaches the person to whom it is given. (3) For the purpose of paragraph (2) a notice "reaches" a person when given to that person orally or delivered at that person's place of business or mailing address. (4) For the purpose of this Article "notice" includes a declaration, demand, request or any other communication of intention."

In addition to the form of notice the aforementioned article lays down the principle that notice or any other kind of communication of intention (declarations, demands, requests, etc.) required by individual provisions of the Principles are not subject to any particular requirement as to form, but may be given by any means appropriate in the circumstances. Which means are appropriate will depend on the actual circumstances of the case, in particular on the availability and the reliability of the various modes of communication and the importance and/or urgency of the message to be delivered. For an electronic notice to be "appropriate to the circumstances" the addressee must expressly or impliedly have consented to receive electronic communications in the way in which the notice was sent by the sender, i.e. of that type, in that format and to that address. The addressee's consent may be inferred from the addressee's statements or conduct, from practices established between the parties, or from applicable usages."

\subsection{2. contracting via web sites}

If a person enters a website, he or she can put a question or selected an option and wait a while to receive the answer. $\mathrm{He}$ or she may put an answer to this site and receive acceptance immediately. In the first case, we will have a contract between absentees and in the second case we will have a contract between those present.

The jurisprudence differed about the natureof electronic contracting. Is this a contract between those present or a contract between absentees?

To answer this question, jurisprudence dividedit into two parts. The first part of the jurisprudence is that,contracting online is a contract between those present where the concept of the contract council applies to both parties, but they have gone to the subject of the contract without being preoccupied by another concern. And they have direct contact over the Internet so that they hear or see each other directly Where there is no time interval between the expression of the will of offer or acceptance, and access to the knowledge directed to him. whileA second part of jurisprudence stated that: Online contracting is a contract between absentees; contracting through this network may be written between contractors $^{21}$.

In addition, a third part of jurisprudence stated that online contracting is a contract between those present in terms of time and a contract between absentees in terms of place. It is considered a contract between those present for the absence of the time interval between the issuance of acceptance and the knowledge of the offeree; it is a contract between absentees in terms of place Such as contracting by correspondence.

In our view, 1 - If the Internet is used in a way that allows voice transmission only, we believe that contracting in this case is a contract between those present in terms of time and absentees in terms of place as is the contract by telephone. 2 - If

21 - OA Badr, Consumer Protection in Electronic Contracting, Comparative Study, New University Publishing House, Alexandria, 2005, P 215. 
it is used as a means of writing and correspondence, such as, an e-mail, the exchange of messages takes place immediately so that there is no time interval between offer and acceptance or was a negligible interval given the e-mail authorization of the instant transmission of exchanged messages, this is also a contract between those present in terms of time and absent in terms of place.

This is which was confirmed by the text of Article 46 which stipulates:" A contract concluded by telephone or by any other similar means shall have the same effect as a contract concluded by persons present in respect of its validity and time, and the contract concluded by correspondence shall be applicable in respect of the place”.

\section{The capacity to conclude an electronic} contract

Article 72 of the Bahraini Civil Code stipulates that:" Every person who has not been declared to be under total or partial legal incapacity, has the legal capacity to conclude a contract".

Through the aforementioned article, it is clear to us that capacitydivided intotwo types: -

First: Capacity of enjoyment which mean that A person's right to assert rights and determine obligations, which is known as legal personality and prove this capacity to the person once born alive and the original that all persons are equal in enjoyment capacity, but the law restricts this capacity exception to some rights.

Second: Capacity of exercise is the authority of the person to initiate legal actions and is affected by a general rule on the age of the person and the degree of discrimination if the original that the human once born proves the capacity to acquire rights and obligations and it does not prove the capacity to direct legal actions.

Age capacity varies into three stages as mentioned in article 74 of civil code "Contracts and other dispositions of property entered into by a minor possessing discretion are valid when wholly to his advantage and void when wholly to his disadvantage.Dispositions of property which may be, at the same time, profitable and detrimental, may be annulled, if this is in the interest of the minor. Annulment cannot be claimed if the act is ratified by the minor upon attaining his legal age or by his guardian or by his curator or by the Minors Estate Guardianship Council or likewise, as the case may be, in accordance with the law".

The requirement of contracting capacity in an ordinary contract is easy to verify because it has been contracted between those present in a single real contract council where each party can ascertain the personality and capacity of the other party by looking at proving his or her personality to the natural person and by reviewing the commercial record of the legal person if he or she is a business, As for the capacity in electronic contracting where contracting is remote, it may be difficult for one of the parties to the contract to verify the capacity of the other contractor and may result in this spatial separation between parties to electronic transactions not knowing all the basic information about each other. It is possible that the website that the contractor deals with is a fictitious site ${ }^{22}$.

The electronic contract must be valid to be issued by contractors who have the capacity to contract. This led the specialists in this field to submit some solutions and suggestions to avoid this defect, the advertising authorities which are a reliable third party neutral from both parties while others see the specialized jurists, the solution is to adopt a legal system to verify the identity of the parties to the electronic contract by any means leading to verification and verification of personal.This means that each party can through this means ascertain the identity of the other party.

It should be noted that the regulation of French consumption in Article 12.18 and the European Directive of 20 May 1997 determined that for

22 - IA Abu-Lil, Legal Aspects of Electronic Transactions, Scientific Publishing Council, Kuwait,2003, P156. 
every offer to sell a product or service to a supplier to ensure that his / her data provide identification data such as the name of the establishment address, e-mail, and obligates the consumer to provide identifying information to his / her personality.

An electronic contract like any other contract that must be validly convened must be issued by contractors who have the capacity to contract. If the parties to the transaction want the contract to be valid, they must review the issue of capacity by any means available provided that the data submitted by a contractor over the Internet may not be correct. In such a case the contractor could not verify the identification data of the other contractor which would certainly affect the validity of the contract if the non-availability of the contract to both parties or one was indeed found.

\section{Object of electronic contract}

The object is the second pillar required by the law in the contractual obligation until the contract is created. If the contract does not have a place to hold, the contract is void and does not entail any effect. Because the electronic contract is often made up of consumer contracts and electronic acceptance is not final therefore the contract is not necessary for the consumer. Acceptance is defined as an expression of the will of the other party who received the offer,and commits to the offeror to inform him of his consent to the offer. The answer to the efferor of the offer and the addition to the offer constitutes the contract ${ }^{23}$.

Acceptance is required to be conformable to the offer on all substantive matters and this acceptance must be accompanied by an existing answer. If the period of the award has expired, the acceptance in this case is considered a new affirmation that needs to be accepted by the other party.
Electronic acceptance does not deviate from the content of this definition except through electronic means through the Internet. It is a remote acceptance subject to the same rules and regulations governing ordinary acceptance, although it has some privacy due to its electronic nature.

It is also known that according to the general rules, the object of the contract must be appointed in two ways, one of which is directly designated by the shop to be fully designated by the appointment of works that are required by the parties. One or both of them and the assignment of such acts to him, and the indirect one in which the premises can be designated later, in the contract, and shall be by means of a statement of the grounds which may be immediately assigned thereafter either in its own right or in its type and ability $^{24}$.

\subsection{Conditions of the object in the electronic contract}

The object is the obligations created by the contract. In this case, it is considered a pillar of obligation but not a stranger to the contract, and therefore what is considered a direct liability of the obligation is at the same time an indirect locus of the contract it generates. "Jurisprudence distinguishes between the object of contract and the object of obligation. The contract is the legal process that the parties intend to achieve under the contract, but the object of obligation is the performance that the debtor commits to the interest of the creditor, namely the act or omission of the act or the giving of ", The conditions to be met in the object of the electronic contract can be summarized as valid contract as follows:

1- The object subject to obligation arising from the contract shall be possible and presentotherwise the contract shall be void.
23 - E Mckendrick, contract law (text, cases, and materials), fifth edition, oxford university press, 2012, P80.

\footnotetext{
24 - E Mckendrick, contract law (text, cases, and materials), fifth edition, oxford university press, 2012, P95.
} 
The contract must be assigned as the Bahraini Civil Code has stated in Article 103, In order for the electronic contract to be assigned to us or to be designated, the product or service shall be described by means of modern communication techniques in a precise and complete manner.

The French Model Contract on Electronic Commerce emphasized the identification of key attributes of the goods and services offered.The first paragraph of Article 4 of this contract referred to the main characteristics of the funds and services presented to the need for a specific mention of the specified funds, their components, dimensions, quantity, colors, special characteristics and other main characteristics. The second paragraph of this contract also specifically referred to the location and content of the services offered.

In this regard, the American law guarantees the so-called express warranty which is the case of the contract based on a sample provided by the seller so that if the sample is considered as a picture of the final product and sample specifications provided for in Article 313/2 of the US Standard Trade Regulations. Thus, it can be said that the description of the products on the network can be considered as a valid guarantee pursuant to the text of the aforementioned article,If the buyer adopts this description mainly.

As stipulated in article 104 of the Bahraini Civil Code regarding dealing with future things at the time of the contract, as the law stipulates:" The object of an obligation shall be things that may happen in the future unless the existence of such things depends on chance.

An agreement with regard to the succession of a living person shall be void, even if he consents to such an agreement, except in cases provided for by law".

2- The object subject to obligation shall be certain and definite beyond any reasonable doubt. Otherwise it shall be void. The object of an obligation shall be determined as to its kind, quantity and degree of its quality, provided that determination of quality does not result in avoidance of the contract. If its kind, quantity and degree of quality cannot be ascertained by usage or by any other circumstances, the debtor shall then supply an article of average quality.

3- A contract is void if its object is contrary to public order or morality.

As in the ordinary contract, there must be object for the electronic contract and the object is specific or assignable and the object in the electronic contract designated by the description of the product or service description of the prevention of ignorance on the computer screen over the Internet, via through web pages or ecatalog.

The purpose of the inspection is to familiarize the sales person with the knowledge that can be realized by its nature and sufficient knowledge is achieved by the consumer with the reality of the sale and the inspection that is achieved by the buyer with the reality of the sale that occurs when the contract is concluded.

The sale is known to the buyer by the description of the item displayed on the website or through the electronic catalog, e-mail or any other electronic means that is sufficiently described in a manner that enables the consumer to understand 
its truth and there will determine its appropriateness for the purpose of the contract is satisfied on the basis of evidence. Request for revocation of the contract, when insufficient knowledge of the product or service is achieved.The description of the commodity or service at the conclusion of the electronic contract shall be a precise and detailed description which shall bring with it sufficient, serious and objective knowledge of the products and services.

The electronic contract must be legitimate in view of the large number of sites that are exploited in the practice of illicit trade such as drugs, libel, slander, defamation of persons, online gambling and money laundering, which are void of the force of law because they are contrary to morality and public order.

However, if the rule is the freedom to sell and deal online, there are some restrictions on the principle of freedom, as exceptions, in order to maintain public order, consumer protection and national interest.

\section{7.consideration of electronic contract}

The consideration for the obligation is the third pillar required by law to be available in the contract and is defined as the direct purpose that is intended to reach it from the obligation.

This definition of reason is not sufficient to determine its content as a pillar of the contract in the obligation because the term direct purpose is not sufficient to derive a specific concept recognizable to its distinctive characteristics ${ }^{25}$.

The cause for the electronic contract is the purpose that the obligor intends to reach through its obligations under the contract. It is noted that any obligation not mentioned in the contract is presumed to have a legitimate cause unless the evidence is otherwise. The reason is that the motive behind the contract is used to protect the legitimacy of the contract and does not eliminate any other part of the contract. By violating public morality, electronic contracts are void.

This is confirmed by Articles 111 and 112 of the Bahraini Civil Code, which states:" Article 111(a) A contract is void when an obligation is assumed without consideration or for a consideration contrary to the public order or morality.(b) An obligation is deemed to have lawful consideration by the motive that urges a contracting party to conclude a contract if the other contracting party was aware of such motive, or should have been aware thereof.", "Article 112: An obligation is deemed to have lawful consideration, even if such consideration is not expressed in the contract, unless the contrary is proved.The consideration expressed in the contract is deemed to be the true consideration until evidence to the contrary is produced. Upon evidence being produced that the consideration is feigned, the onus falls on the person who maintains that the obligation has another lawful consideration of proving his contention".

It is clear from the aforementioned texts that the consideration is intended for the purpose intended by the obligor behind the obligation, the reason is based on the availability of three conditions:

\section{1- Existence of consideration}

The consideration must exist. But If does not exists the contract is null and void. If a person is forced to sign a debt bond and is not indebted or is unwilling to donate and has no intention of making a donation, the contract is null and void.This means that in the netting contracts the cause for the obligation of one party is in itself the object of the other party's obligation. If this object was destroyed before the contract was concluded, there is no reason for the obligation and also if the obligation of either party is an act or omission. An absolute contract is not held and there is also no reason for obligation.

\section{2- Validity of consideration}

25 - Richard stone, the modern law of contract, tenth edition, published by routledge, new yourk,2013, P35. 
It is also required that the consideration should be valid and the cause is invalid if he is hypocritical or visionary. The example of the cause is that he goes out and inherits with a person who believes he is an heir then it turns out that he is not an heir or the heir agrees with a testator to give him a sum of money and it turns out that the testator returned in his will in such assumptions the contract is invalid for no reason.

\section{3- Legality of consideration}

The cause should be lawful, and will be if it does not violate public order or morals. If a person commits a crime in exchange for a sum of money, the obligation of a pledge to pay the money is null and void because the other person committed the crime. The obligation is also void because of the illegality of the object. The corresponding obligation is to pay a sum of money, but it is invalid because it is not lawful to commit the crime.

The reason for the ordinary contract is not different from the reason why electronic contracts are made through modern communication techniques which may include, for example, obscene acts which are invalid because the reason is illegal. However, the concept of public morality evolves gradually over time and varies from state to state by modern Society. Therefore, what is considered to be contrary to public morality in a State may not be so in another State, which of course requires the need for coordination among States at the regional and international levels ${ }^{26}$.

\subsection{The distinction between consideration and motivation}

The cause is different from the motivation that the motive is the personal incentive that makes the contractor conclude the contract and the cause is objective. The motives vary according to the

\footnotetext{
26 - E peel,B.CL., M.A., The law of contract, 2011, thirteen editions, published by sweet\&Maxwell, London, 2011, P172.
}

subjective desire of each contractor in each contract.

It is known that the reason is in fact the pillar of the will of the owner and not a pillar in the contract itself that is in the bilateral contracts where each of the contractors willingly and each of the two will cause them.

\subsection{Consideration for different contract types}

The cause for the obligation in contracts varies according to each type. The cause can be addressed in contracts binding to both sides of the contract and contracts binding to one party and donation contracts.

First: -Consideration for binding bilateral contract:

In the binding bilateral contract, the reason for the obligation of each of the contractors is to obtain the obligation.

Second: - Consideration in binding unilateral contract

In unilateral binding contract, the cause is the receipt of the object of obligation, and on this basis the cause for the deposit contract is the receipt of the thing deposited.

Third: - Consideration for donation contracts

The cause for donation contracts is the intention of the donor itself. The purpose of the donation is to provide a well-known donation to the person who donated it.

It is noted that in general, there is nothing of privacy for the cause of the contract. Namely the electronic contract, where, in this respect, it is governed by its general rules.

\section{8.Conclusion}

One of the basic components of the electronic contract is consent which consists of offer and acceptance.Moreover, we consider that the offer is the first step in concluding all contracts, including the electronic contract. Therefore, the offer is the first that will appear in the contract. 
In addition, acceptance through electronic means i.e. through the Internet does not deviate from its definition in the general rules and all that is done by means of electronic. Because of the recent way some countries have been concerned to issue their legislation in relation to electronic transactions. The contract council isone of the greatest importance in the formation of the contract and is considered the most important stage in the formation of the contract.

\section{ABOUT THE AUTHORS}

Dr Yassin Ahmad alqudah,assistant professor, College of Law/ private law, Middle East University.

Dr. Raed Mohammad Flieh Alnimer, assistant professor, College of Law/ private law, Royal University for Women

\section{CONFLICT OF INTEREST}

The author confirms that this article content has no conflict of interest.

\section{ACKNOWLEDGEMENTS}

The authors grateful to the Middle East University, Amman, Jordan, for the full financial support granted to this research project.

\section{References}

[1] Alfar, Abdul Qadir: sources of obligation, sources of personal right in civil law, 2001, First Edition, Jordan, International Scientific House, and Dar Al Thaqafa Library for Publishing and Distribution.

[2] Ibrahim, Khaled Mamdouh,2006, conclusion of the electronic contract comparative study, First Edition, Alexandria, published dar alfker aljamee.

[3] Aljmal, Samir Hamid, 2006, Contracting through modern communication techniques (comparative study), First Edition. Cairo: Dar Al-Nahda Al Arabia.
[4] Ahmed, Amang Rahim,2006, Consensus in Electronic Contracts via the Internet a Comparative Analytical Study in the Light of the Iraqi Civil Code and the Laws of Commerce and Electronic Transactions in (USA, Canada, Tunisia, Jordan, Kingdom of Bahrain, Emirate of Dubai) and the UNCITRAL Model Law on Electronic Commerce. First Edition. Amman: Wail Publishing library.

[5] Al-Wathaq Atta Al-Manan,2008, The legal framework of the electronic contract, first edition.

[6] Osama Abu Hassan Mujahid, 2005, Online contracting, Legal Library, Egypt.

[7] Sultan, Anwar, 1958, The General Theory of obligations. part One. Second Edition. Egypt: Dar Al Ma'arif.

[8] Khaled Hamdi Abdel Rahman,2005, Expression of Will in the Electronic Contract, Dar Al-Nahda Al Arabiya, Cairo.

[9] Khalid Mamdouh Ibrahim, 2006, conclusion of the electronic contract, the Arab Thought House, Alexandria.

[10] Osama Ahmed Badr, 2005, Consumer Protection in Electronic Contracting, Comparative Study, New University Publishing House, Alexandria.

[11] Samir Hamed Abdulaziz Al-Gammal, 2000, Contracting Through Modern Communication Technologies, First Edition, Dar Al-Nahda Al-Arabiya, Cairo.

[12] Mohammed Amin Al Roumi,2004, Online E-Contract, First Edition, University Press House, Alexandria.

[13] Ibrahim Al-Dessouki Abu-Lil, 2003, Legal Aspects of Electronic Transactions, Scientific Publishing Council, Kuwait.

[14] Mamdouh Mohamed Ali Mabrouk,2011, The Authenticity of the Electronic Signature in Proof, Dar Al-Nahda AlArabiya, Cairo. 
[15] Ahmed Khaled Al Ajlouni, 2002, Online Contracting, Master Thesis, University of Jordan.

[16] Ewan Mckendrick, 2012, contract law (text, cases, and materials, fifth edition, oxford university press.

[17] Chris Monaghan, Nicola Monaghan, 2014, Beginning contract law, Routlege taylor\&francis group, London and New York.

[18] Richard stone. 2013, the modern law of contract, tenth edition, published by routledge, new yourk.

[19] Edwin peel,B.CL., M.A., The law of contract, 2011, thirteen editions, puplished by sweet\&Maxwell, London. 